\title{
IMPACT OF THE COVID-19 PANDEMIC ON ISLAMIC BANK INDICES OF THE GCC COUNTRIES
}

\author{
Dr. Shakeel UI Rehman \\ Assistant Professor \\ Department of Management Studies \\ School of Business Studies \\ E-mail: rehman.shakeel@ islamicuniversity.edu.in \\ Yasser Saleh Ali Almonifi \\ Department of Finance \& Banking Sciences \\ Faculty of Administrative Sciences \\ Thamar University, Yemen \\ E-mail: almonifi1987@gmail.com \\ Dr. Rafia Gulzar \\ Assistant Professor \\ Department of Human Resource \\ College of Business \\ Dar Al Uloom University, Riyadh-133140 \\ Kingdom of Saudi Arabia \\ E-mail: rafia@dau.edu.sa
}

Islamic University of Science \& Technology, Awantipora-192122, J\&K, India

Received: September 01, 2021 Accepted: October 01, 2021 Online Published: October 11, 2021

DOI: 10.46281/ijibfr.v7i1.1381

URL: https://doi.org/10.46281/ijibfr.v7i1.1381

\begin{abstract}
The present study explores the impact of the COVID-19 pandemic on Islamic bank indices in GCC countries banking sector. The research aims to know the ability of Islamic Bank indices to face the COVID-19 crisis and examine whether Islamic bank indices can respond to the volatility in the stock exchanges. The study uses data of stock exchanges and Dow Jones Islamic Market Index in GCC countries banking sector to relate the data before and during the COVID-19 crisis. It is found that Islamic banks have ability to respond the financial and economic crisis. Also, Islamic banks are able to provide their valuable services continuously and perform their financial activities during and after the crisis competently. The results also indicate that Islamic Bank Indices in GCC countries have performed better during 2019 with significant closing prices compared to 2020. As during 2020 fifteen banks recorded normal decreasing in its indices and six Islamic banks achieved growth in its indices. In Q1, Q2 of 2021 the Islamic banks achieved positive growth in its indices price. This specifies that Islamic Banks have managed the financial and economic crisis in an efficient manner.
\end{abstract}


Keywords: Islamic Banks, The COVID-19 pandemic, Islamic Indices, Banking Sector, GCC Markets, Dow Jones Islamic Market Index.

JEL Classification Codes: E44, E58, G24, G18, H12.

\section{INTRODUCTION}

COVID-19 has affected the economic and social sectors in wide parts of the world and has caused the emergence of a global economic crisis which affected most of the countries (the developed and developing countries) around the world. In GCC region, the interest in Islamic financial industries has grown in the past decades. Currently the Islamic banking needs standards and procedures to measure the performance of Shariah-compliant investments. The Islamic economic system needs Shariah-compliant indices to control and evaluate the performance of companies listed in stock exchanges. Currently, Shariah-compliant indexes are applied in stock exchanges and achieve high returns, such as the Dow Jones Islamic Market Indexes (DJIMI), which was established in Bahrain in December 1999, as well as the FTSE Global Islamic Series (GIIS) in 1999 index created by Islamic Investment Bank.

The Investors in stock exchanges of GCC countries have motivation and high preference to deal with the Islamic banks and companies shares listed under Islamic indices, also it is evidence to increase the trading volume for the Islamic shares and growing the Islamic indices in the financial markets, and this confirms confidence of investors in the Islamic financial companies and institutions which are listed under these indices. The Islamic banks in GCC countries help to develop Islamic investments, finance and insurance. Due to the economic importance for the Gulf region, the DJ GCC Islamic Index was established to measure performance of Shariah-compliant companies listed in GCC countries stock exchanges. The present study contributes to the existing literature in order to identify the effects of COVID-19 financial crisis on indices of the Islamic financial institutions and banks in GCC countries, and DJ GCC Islamic Index for GCC countries. The study includes stock exchanges in Saudi Arabia, Bahrain, Oman, Kuwait, Qatar and the United Arab Emirates as shown in table 1.

Table 1. GCC Indices and Methodology

\begin{tabular}{|c|c|c|}
\hline Country & Index & Methodology \\
\hline GCC & Dow Jones Islamic Market Index GCC & Modified market cap weighted \\
\hline Saudi Arabia & Tadawul All Share TASI Index & Capitalization-weighted \\
\hline UAE & Abu Dhabi Securities Market G Index & $\begin{array}{l}\text { Float-adjusted market } \\
\text { capitalization }\end{array}$ \\
\hline Kuwait & Kuwait Stock Exchange Index & Price-weighted \\
\hline Oman & Muscat Securities MSM 30 Index & Capitalization-weighted \\
\hline Qatar & Qatar Exchange Index & Capitalization-weighted \\
\hline Bahrain & Bahrain Brouse All Share Index & Capitalization-weighted \\
\hline
\end{tabular}


The financial markets in GCC have achieved a significant increasing in capitalization due to the economic growth and the positive role for GCC economies, as well as the economic importance for GCC financial markets compared to the global financial markets. Table 2 provides the value of market capitalization of GCC financial markets at the end of 2019, 2020 and June 2021.

Table 2. Market Capitalization

\begin{tabular}{|l|c|c|c|}
\hline \multirow{2}{*}{ Market } & \multicolumn{3}{|c|}{ Value of Market Capitalization (Billion Dollar) } \\
\cline { 2 - 4 } & December 2019 & December 2020 & June 2021 \\
\hline Saudi Arabia & 529.52 & 556.19 & 731.69 \\
\hline UAE* & 123.32 & 141.93 & 205.71 \\
\hline Kuwait & 118.18 & 106.97 & 123.52 \\
\hline Oman & 48.79 & 53.24 & 56.06 \\
\hline Qatar & 160.05 & 165.44 & 170.99 \\
\hline Bahrain & 26.88 & 24.61 & 26.31 \\
\hline
\end{tabular}

Source: GCC stock markets Indices \& extracted from www. argaam.com

*Abu Dhabi \& Dubai Stock Markets

According to Dow Jones Islamic Index, Saudi Arabia owns 72.6 per cent (as shown in table 3) of the total companies listed under the Dow Jones Islamic Index, the top three banks by the index weight are Al Rajhi Banking \& Investment Corporation, Alinma Bank \& Masraf Al Rayan Bank.

Table 3. Constituents \& Indices weight per cent, June 2021

\begin{tabular}{|l|c|c|c|}
\hline \multicolumn{1}{|c|}{ Country } & $\begin{array}{c}\text { Number of } \\
\text { Constituents }\end{array}$ & $\begin{array}{c}\text { Total Market Cap (Billion } \\
\text { USD) }\end{array}$ & Index Weight percent \\
\hline Saudi Arabia & 68 & 2336.09 & 72.6 \\
\hline Qatar & 12 & 83.92 & 11.7 \\
\hline Kuwait & 15 & 40.53 & 7.5 \\
\hline UAE & 8 & 90.45 & 7.5 \\
\hline Bahrain & 2 & 1.1214 & 0.4 \\
\hline Oman & 7 & 1.925 & 0.3 \\
\hline
\end{tabular}

Source: DJIM GCC Index (Fact Sheet)

The Dow Jones Islamic Market Index includes many economic sectors (see figure 1). Banks and financial institutions constitute about 31 per cent of the total index as of 30 June 2021 (S\&P Dow Jones Indices, June 2021). 


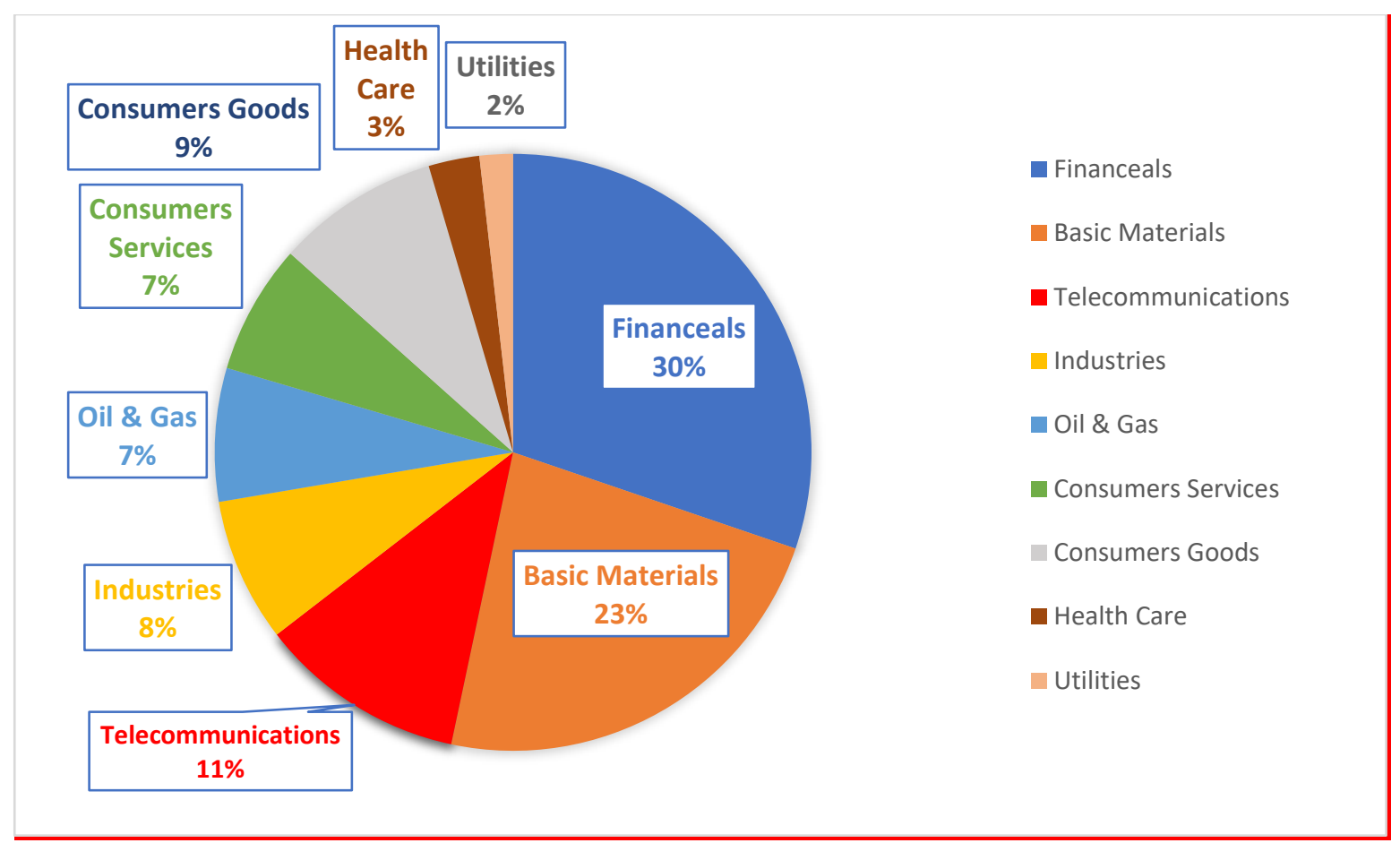

Figure 1. Sector allocation for DJIM GCC Index, June 2021 Source: S\&P Dow Jones Indices -Fact Sheet

As evidenced, Sharia-compliant investments are less risky compared to conventional investments. The Islamic investments have been able to respond to economic shocks which affect most investments, such as COVID-19 crisis. As the study attempts to explore the impact of COVID19 crisis on the Islamic indices in GCC, it depends on comparing the averages and variances of the Islamic Bank Indices during the period from January 2019 to June 2021.

\section{BACKGROUND OF THE STUDY}

Here the researcher tries to refer some important studies related to performance of Islamic banks with reference to 2007-08 financial crises and the COVID-19 pandemic. The impact of global financial crisis 2008 on Islamic banks compared to conventional banks based on accounting ratios as studied by Zehri, Abdelbaki, and Bouabdellah (2012) supports that Islamic banks are more stable than conventional banks during crisis of 2007-08. Likewise Miniaoui, Syani and Chaibi (2015) examine performance of Islamic and conventional indices in GCC countries during the financial crisis of 2008. The results found that financial crisis impacted on returns of Bahrain market, while other indices remained unaffected, the financial crisis impacted volatility in three GCC markets, Kuwait, Bahrain, and UAE, the impact on markets of Saudi Arabia, Oman, and Qatar was insignificant, also that Islamic index did not exhibit lower volatility than its conventional counterparts. Further Kassim (2010) explored impact of the global financial crisis 2008 on integration of Islamic financial markets. The results show strong correlation between Islamic financial markets during the crisis.

The impact of the global financial crisis on stock markets of Pakistan and India during the period from January 2003 to August 2010 was examined by Ali and Afzal (2012), the study found that negative shocks have more pronounced impact on the volatility than positive shocks, and the stock markets faced persistent volatility clustering, the global financial crisis made mild negative 
impact on stock returns and enhanced volatility in Pakistan and Indian stock exchanges but this impact is stronger on Indian stock market. Similarly, Sukmana and Kolid (2010) investigated impact of 2007-2008 global financial crises on Islamic stock index compare to conventional stock in Indonesia. The results show that investments in Islamic stock index are less risky than conventional indices. Further, Njiforti (2015) investigated the impact of 2007-2008 global financial crisis on the Nigerian capital market from January 2006 to December 2009. It is found that the global financial crisis significantly affected the Nigerian capital market both in the short run and long run. Wasiuzzaman (2010) explored impact global crisis of 2007-2008 on Malaysian financial market by use GARCH models. The study found that there was an increase in the impact of news about volatility from the previous periods but only a slight drop in the persistency of the conditional variance.

While Thalassinos, Pintea, and Iulia (2015) examined the performance of stock market indices during the global financial crisis in several countries. The results show that financial crisis negatively affected the indicators in the selected countries (Western European countries, Japan and USA). Moreover, Erfani and Vasigh (2018) investigate effects of global financial crisis 2008 on efficiency and profitability of Islamic and commercial banks during period from 2006 to 2013. The study found that Islamic banks managed to maintain their efficiency while most commercial banks suffered a loss in their efficiency, and financial crisis did not have a significant impact on profitability of Islamic banks.

Similarly, Chaouachi and Slim (2020) explored the effect of COVID-19 pandemic on stock market in KSA during period from $2^{\text {nd }}$ March, 2020 to $20^{\text {th }}$ May, 2020, by analyzes the relationship between the natural logarithm of trading volume of Tadawul All shares index and the natural logarithm of daily COVID-19 confirmed cases. The study found that there is a negative impact of COVID-19 on stock market only in the long-run. Similarly, El-Basuony (2020) identified the impact of the COVID-19 on the Arab financial markets during the period from $1^{\text {st }}$ April, 2020 to 21 May 2020 in Egypt and KSA. The study found that there is a negative significant relationship between the confirmed cases and death cases of the COVID-19 pandemic. The COVID-19 pandemic had a significant impact on the financial markets from $1^{\text {st }}$ April 2020 to 21th May 2020 in Egypt and KSA. Moreover Aldasoro, Fender, Hardy, and Tarashev (2020) empirically ascertains impact of the COVID-19 crisis on the banking sector. The data revealed that the size and scope of the COVID-19 crisis are more impact compare to the great financial crisis of 200709 . The study concluded that the initial market reaction was a tsunami that engulfed many banks, and the best-capitalized and more profitable banks were able to face the shocks of crisis. Further Irfan, Kassim, and Dhimmar (2020) explores the impact of the COVID-19 pandemic crisis on the Islamic stock markets in Indian Stock Exchange (represented by the Bombay Stock Exchange BSE Shariah Index) and Indonesian Stock Exchange (represented by the Jakarta Islamic Indices). The results show that the BSE Shariah and JII have positive coefficients, with the BSE Shariah Index shows negative response to the announcement of the COVID-19 as global pandemic. On the other hand, the JII reacted positively to the event, and that reaction of a stock exchange is dependent on other economic factors unique to the country.

The impact of the COVID-19 confirmed cases and deaths on the daily returns of the major stock market indices in the GCC countries over the period from $1^{\text {st }}$ April 2020 to June $26^{\text {th }}, 2020$ was investigated by Bahrini and Filfilan (2020). The study found that stock markets in the GCC countries responded negatively and with a great degree to new and total COVID-19 confirmed deaths, while response to the number of the COVID-19 confirmed cases is not significant, also, the returns of the major stock market indices in the GCC countries declined when the confirmed 
deaths increased. The study of Shehar Yar (2020) concluded that only COVID-19 recoveries are influencing the performance of the Pakistani Stock Market Index and the daily positive cases and fatalities are insignificantly related to the performance Index. Hidayat, Farooq, and Alim (2020) investigated the impact of the COVID-19 pandemic outbreak on Islamic finance in the OIC Countries. The study concluded that Islamic banks are able to innovate and continue to provide financing during the crisis, also Islamic banks have a positive impact during the crisis and they are able to provide finance and meet the needs of society, and Islamic economies have taken maximum measures to achieve stability in the finance industry and reduce impact of the crisis on Islamic finance.

While Abdullahi (2021) aims to analyze and measure cross-country stock market correlation and volatility transmission during the global the COVID-19 disease pandemic and traces trajectory of Islamic equity investments in order to get insights on behavior of the markets. The normal correlation analysis on the share indices shows that markets move together and the markets returns are cointegrated as a group, and that COVID-19 affected on all share indices equally. Further Sutrisno, Panuntun, and Adristi (2020) examined the impact of COVID-19 on six stock market indexes of countries listed on ASEAN exchanges and three stock market indexes of countries listed on ASEAN exchanges. The results showed that all variables tested had a highly significant degenerating long-term relationship due to the impact of the COVID-19 pandemic, and there was a relationship between the COVID-19 pandemic and the return on the country's stock market.

Ali, Anwar, and Haseeb (2021) explore the reaction of the Indonesian stock market to COVID-19 by use the continuous wavelet coherence methodology to daily COVID-19 deaths and daily conventional and Islamic stock indices in Indonesia. The result found that COVID-19 negatively impacted the returns of both indices and enhances their volatility, also Islamic stock index is more volatile compared to its conventional counterpart during the COVID-19 outbreak. Likewise, Sansa, and Hasan (2020) investigate the impact of COVID - 19 on the financial markets during the period from $1^{\text {st }}$ March 2020 to $25^{\text {th }}$ March 2020 in Shanghai Stock Exchange and New York Dow Jones. The study found that there is a positive significant relationship between the COVID - 19 confirmed cases and all the financial markets (Shanghai stock exchange and New York Dow Jones).

Another study by Almonifi, Rehman, and Gulzar (2021) on the COVID-19 pandemic effect on the performance of the Islamic Banking Sector in KSA, found that the impact of risks of the COVID-19 crisis on Islamic banks is very low and Al Rajhi Bank was able to respond to all economic and financial shocks. The impact of Covid-19 on Shanghai Stock Exchange during the first quarter of 2020 was studied by Saleh (2020). The results reveal that Covid-19 has affected Shanghai Stock Exchange negatively. Further, Ganar et al. (2020) explored the impact of the COVID-19 pandemic on Islamic stock index in Indonesia. The research results are expected to be used as consideration for companies, investors, and stakeholders in anticipating future pandemic events. It can be summarized that more or less the financial crises of 2007-08 and also the COVID19 pandemic is having significant impact on the indices of Islamic banking.

\section{OBJECTIVES}

To explore the impact of the COVID-19 crisis on Islamic indices for financial markets in GCC countries: banking sector, during the period from January 2019 to June 2021. 


\section{METHODOLOGY}

The study depends on secondary data and uses the descriptive approach to investigate the indices of Islamic banks listed under the GCC stock exchanges for the period from January 2019 to June 2021 (Annual average for daily data). The study applies the analytical approach to examine the impact of the COVID-19 pandemic on Islamic banks indices, and compare the Islamic bank index performance between the period before the COVID-19 crisis and the period during the COVID19 crisis.

\section{Background of Stock Markets in GCC Countries}

The GCC stock markets witnessed high growth in volumes of the transactions and international capital flows which contributed to develop economic growth rates and manage capitals and economic projects in GCC countries. The indices of GCC stock markets maintained their performance and returns which reflects the continued improvement in markets and indices, the trading activity improved in the listed sectors, especially the banking sector, services, investment, health care and technology. The improvement in international oil prices and performance of global financial markets positively affect GCC stock exchanges during 2021, the stock exchanges witnessed some decline in their index's performance during 2020 due to the COVID-19 crisis. The GCC market indices increase during the first and second quarters of 2021 in different levels, Abu Dhabi stock exchange index grew by 35 per cent, Saudi market index achieved the most increase by 26 per cent, Kuwait market index 15 per cent, Dubai financial market index 13 per cent, Muscat market index 11 per cent, Bahrain market index 7 per cent and Qatar market 3 per cent (S\&P Dow Jones Indices, June 2021).

\section{Impact of the COVID-19 Crisis on Stock Markets in GCC Countries}

The performance of Arab financial markets declined significantly during the first quarter of 2020 compared to 2019 due to the economic effects related to the COVID-19 crisis and the sharp decreasing in oil prices worldwide, therefore, closing prices for all GCC financial markets declined (Arab Monetary Fund, Q1 2020). The GCC financial markets were affected during 2020 by the COVID-19 crisis and the closing procedures to limit the spread of the epidemic, and the changes that occurred by increasing in weight of companies' shares listed in markets of UAE and Saudi Arabia in particular, also Kuwait joined list of global stock indices, whether FTSE or Morgan Stanley are main factors affected performance of GCC financial markets during 2021. Also, the COVID-19 crisis caused a significant decreasing in oil and stock prices in GCC stock exchanges, this led to collapse of financial market indices in GCC countries and global markets. The COVID19 crisis also caused decrease in demand for companies and banks shares. During the first quarter of 2020, volume of the major bank's shares in GCC Countries decreased by 25 per cent.

At end 2020 and beginning of 2021, the indices of GCC stock exchanges increased due to positive factors such as improving business results, the increasing in initial offerings, high oil prices and stimulus plans and economic support. The performance of GCC financial markets improved in the first quarter of 2021, Abu Dhabi index increased 17. 2 per cent, Saudi Arabia 14.2 per cent, Kuwait 4.5 per cent, Dubai 2.3 per cent and Muscat 1.4 per cent, while Qatar index decreased by 0.3 per cent and Bahrain index 2.1 per cent, table 4 shows indices of GCC stock exchanges during study period. 
Table 4. GCC stock exchanges Indices

\begin{tabular}{|l|c|c|c|}
\hline \multicolumn{1}{|c|}{ Country/Index } & $\mathbf{2 0 1 9}$ & $\mathbf{2 0 2 0}$ & Q1, Q2 2021 \\
\hline Saudi General Index (TASI) & $8,445.92$ & $7,747.80$ & $9,951.62$ \\
\hline Tadawul 30 Index (MISAT0002PSA) & $1,227.16$ & $1,050.08$ & $1,346.52$ \\
\hline Abu Dhabi Index (ADI) & $5,104.50$ & $4,538.54$ & $6,101.77$ \\
\hline Dubai Market Index (DFMGI) & $2,699.91$ & $2,243.59$ & $2,670.56$ \\
\hline Manama Market Index (BAX) & $1,484.47$ & $1,418.93$ & $1,497.92$ \\
\hline Qatar Market Index (QSI) & $10,326.01$ & $9,528.30$ & $10,568.56$ \\
\hline Kuwait Market Index (BKP) & $6,193.18$ & $5,869.93$ & $6,489.17$ \\
\hline Muscat Market Index (MSX30) & $3,990.64$ & $3,672.77$ & $3,775.22$ \\
\hline
\end{tabular}

Source: GCC stock markets \& extracted from sa.investing.com.

Table 4 includes the annual average for GCC stock exchange indices prices during period 2019, 2020, and 1Q, 2Q of 2021, the data show clear impact of the COVID-19 crisis on the indices during year 2020. The indices performance is improving in 2021 compared to the performance before COVID-19 crisis in 2019 (see figure 2).

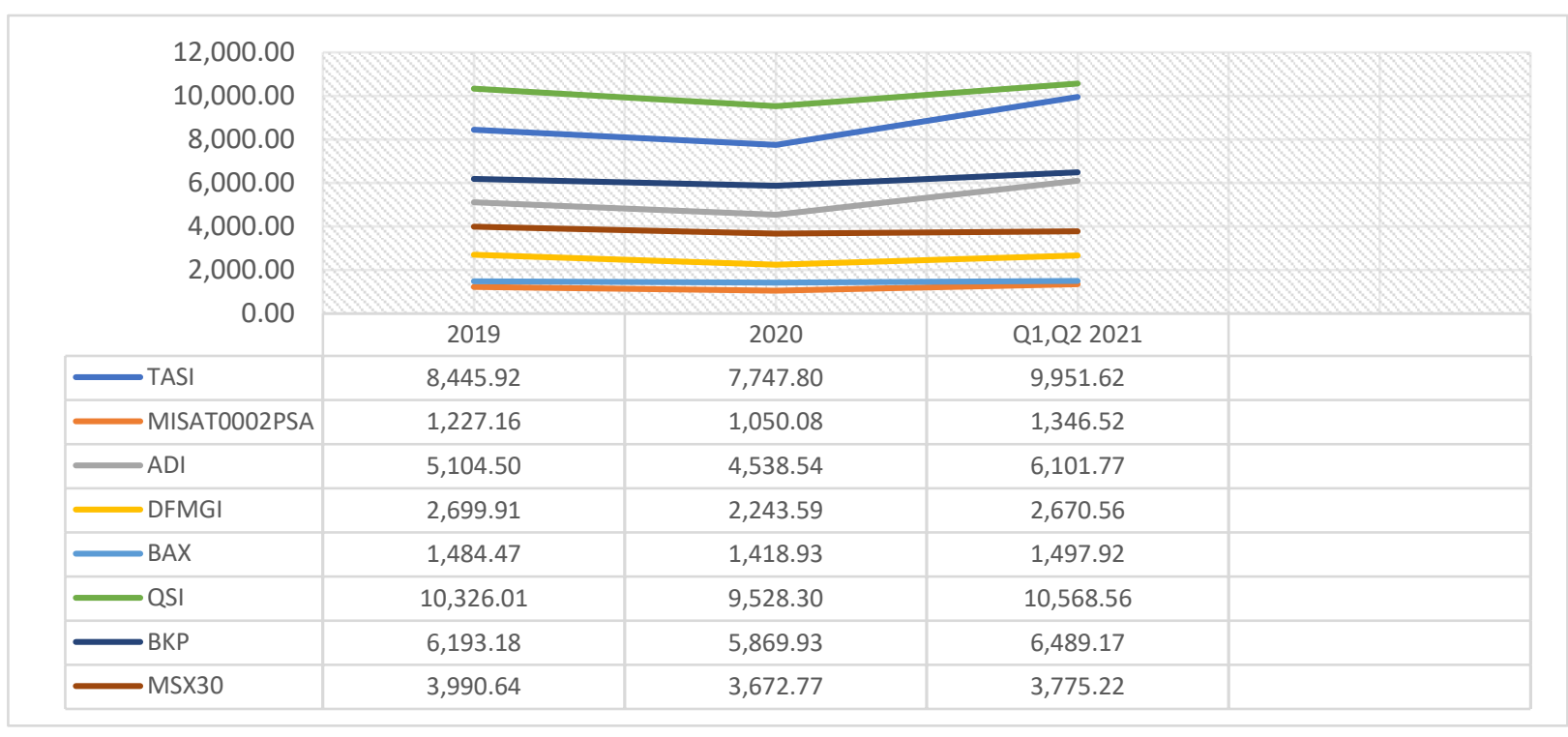

Figure 2. GCC stock exchanges Indices Source: Table 4

\section{The Islamic Banks Under Study Listed in GCC Stock Exchanges}

Islamic banks in GCC countries are characterized by their increased financial assets, and growth in the markets, also GCC Islamic banks have proven their ability to work in banking finance market and achieve standard indices despite the change in exchange rates, and fluctuations in oil prices and global crises such as the COVID-19 pandemic. Islamic banks in GCC ranked at the third level for Islamic bank's assets worldwide, according to the Arab Monetary Fund in June 2017. In Saudi Arabia, Al-Rajhi Bank is the tope Islamic bank in GCC countries with financial assets estimated at $\$ 91.49$ billion, and Qatar Islamic Bank is considered the third largest Islamic bank worldwide 
with assets of $\$ 47$ billion. The total assets of Islamic banks in GCC countries amounted about $\$ 477$ billion in 2020 .

Table 5. Main Islamic banks listed in GCC stock markets

\begin{tabular}{|c|c|c|}
\hline Country & Stock exchange & Banks \\
\hline \multirow[t]{7}{*}{ Saudi Arabia } & \multirow[t]{7}{*}{ Tadawul } & Saudi National Commercial Bank \\
\hline & & Arab national Bank \\
\hline & & Bank Albilad \\
\hline & & Bank AlJazira \\
\hline & & Riyad Bank \\
\hline & & Alinma Bank \\
\hline & & Al Rajhi Bank \\
\hline \multirow{3}{*}{$\begin{array}{l}\text { United } \\
\text { Emarat }\end{array}$} & \multirow{3}{*}{$\begin{array}{l}\text { Abu Dhabi Market } \\
\text { \& Dubai Market }\end{array}$} & Dubai Islamic Bank \\
\hline & & Abu Dhabi Islamic Bank \\
\hline & & Sharjah Islamic Bank \\
\hline \multirow[t]{4}{*}{ Bahrain } & \multirow[t]{4}{*}{ Manama Market } & Albaraka Islamic Bank \\
\hline & & ABC Bank \\
\hline & & GFH Financial Group- Bank \\
\hline & & Bahrain Islamic Bank \\
\hline Oman & Muscat Market & Bank Nizwa \\
\hline \multirow[t]{3}{*}{ Qatar } & \multirow[t]{3}{*}{ Qatar Market } & Qatar Islamic Bank \\
\hline & & Qatar International Islamic Bank \\
\hline & & Masraf Al Rayan \\
\hline \multirow[t]{3}{*}{ Kuwait } & \multirow[t]{3}{*}{ Kuwait Market } & Kuwait Finance House \\
\hline & & Boubyan Bank \\
\hline & & Warba Bank \\
\hline
\end{tabular}

Source: GCC stock markets

The contribution of Arab countries in the Islamic finance sector more than 55 per cent of industry volume worldwide. Most Arab countries adopt regulations and legislation for Islamic finance, Islamic banks, Islamic sukuk, financial markets, and takaful insurance. Islamic banks have legal importance in most Arab countries, especially Sudan, Saudi Arabia, Emirates, Jordan, Bahrain, Qatar and Kuwait, for these reasons, Islamic banks have become an essential component in GCC financial markets (Arab Monetary Fund, 2021). The study focused on the main Islamic banks listed in GCC stock markets, total 21 Islamic banks, as shown in table 5.

\section{ISLAMIC BANKS INDEXES IN GCC STOCK EXCHANGES}

This section analyze the annual average of daily closing prices for indexes of the Islamic banks in GCC stock exchanges.

\section{Islamic Banks Indices listed in Saudi Market}

Saudi Arabia plays a leading role in field of Islamic banking worldwide, the Islamic banking finance globally amounted to about \$3 trillion, its value in Saudi Arabia is 299 billion dollars, representing 10 per cent of the global finance, and Islamic finance in Saudi Arabia constitutes 80 per cent of its total finance sector (Noor, 2020). 
Table 6. Analysis of Islamic Banks Indices in Saudi stock market

\begin{tabular}{|c|l|c|c|c|}
\hline Country/Market & \multicolumn{1}{|c|}{ Banks } & $\mathbf{2 0 1 9}$ & $\mathbf{2 0 2 0}$ & Q1, Q2 2021 \\
\hline \multirow{3}{*}{ Saudi Ariba } & $\begin{array}{l}\text { Saudi National } \\
\text { Commercial Bank }\end{array}$ & 51.63 & 39.55 & 50.49 \\
\cline { 2 - 5 } & Arab national Bank & 24.64 & 20.84 & 21.14 \\
\cline { 2 - 5 } & Bank Albilad & 25.53 & 24.08 & 26.65 \\
\cline { 2 - 5 } & Bank AlJazira & 15.08 & 12.92 & 15.90 \\
\cline { 2 - 5 } & Riyad Bank & 24.29 & 18.89 & 23.24 \\
\cline { 2 - 5 } & Alinma Bank & 17.94 & 16.02 & 18.01 \\
\cline { 2 - 5 } & Al Rajhi Bank & 66.04 & 62.87 & 92.31 \\
\hline
\end{tabular}

Source: GCC stock markets \& extracted from sa.investing.com

The Islamic banks indices of seven banks listed in the Saudi financial market is shown in table 6, and linear direction for the indices shown in figure 3 below.

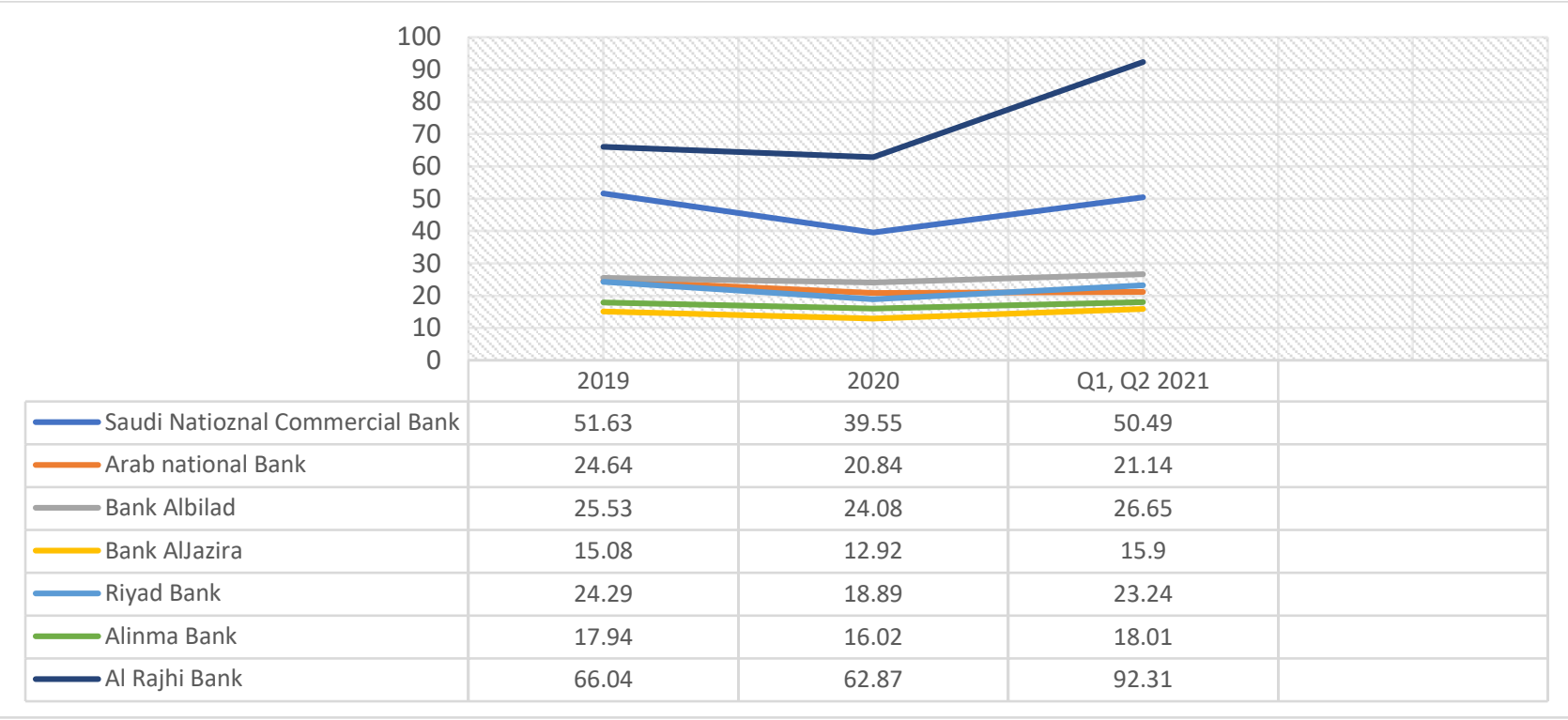

Figure 3. Islamic Banks Indices listed in Saudi market

Source: Table 6

\section{Islamic Banks Indexes listed in UAE Market}

According to company of Alpen Capital (2021) the Islamic banks in UAE recorded an improvement in its performance during 2020, the assets grew by 5.3 per cent, equal to $\$ 162.7$ billion compared to $\$ 154.5$ billion in 2019 . Islamic banks in UAE recorded a higher growth compared to the conventional banks assets, the market share improved with a growth rate 6.8 per cent in finance which consists the private companies and retail finance. UAE has three of the top ten Islamic banks in the world, Dubai Islamic bank is the second in world after Al Rajhi Bank, with assets of $\$ 78.2$ billion at end of 2020, Abu Dhabi Islamic bank with assets of $\$ 34.51$ billion, and Sharjah Islamic Bank with assets of $\$ 14.47$ billion. Islamic assets in UAE recorded a cumulative growth 7.7 per cent during period from 2014 to 2019 to reach $\$ 234$ billion, equivalent 
to 8 per cent of total global Islamic assets. The Islamic banks indices of three banks, listed in United Arab Emarat financial market is shown in table 7, and linear direction for the indices shown in figure 4 below.

Table 7. Analysis of Islamic Banks Indices listed in UAE market

\begin{tabular}{|c|l|c|c|c|}
\hline Country/Market & \multicolumn{1}{|c|}{ Banks } & $\mathbf{2 0 1 9}$ & $\mathbf{2 0 2 0}$ & Q1, Q2 2021 \\
\hline \multirow{2}{*}{ UA Emirates } & Dubai Islamic Bank & 5.17 & 4.30 & 4.77 \\
\cline { 2 - 5 } & Abu Dhabi Islamic Bank & 4.79 & 4.28 & 5.07 \\
\cline { 2 - 5 } & Sharjah Islamic Bank & 1.11 & 1.14 & 1.38 \\
\hline
\end{tabular}

Source: GCC stock markets \& extracted from sa.investing.com.

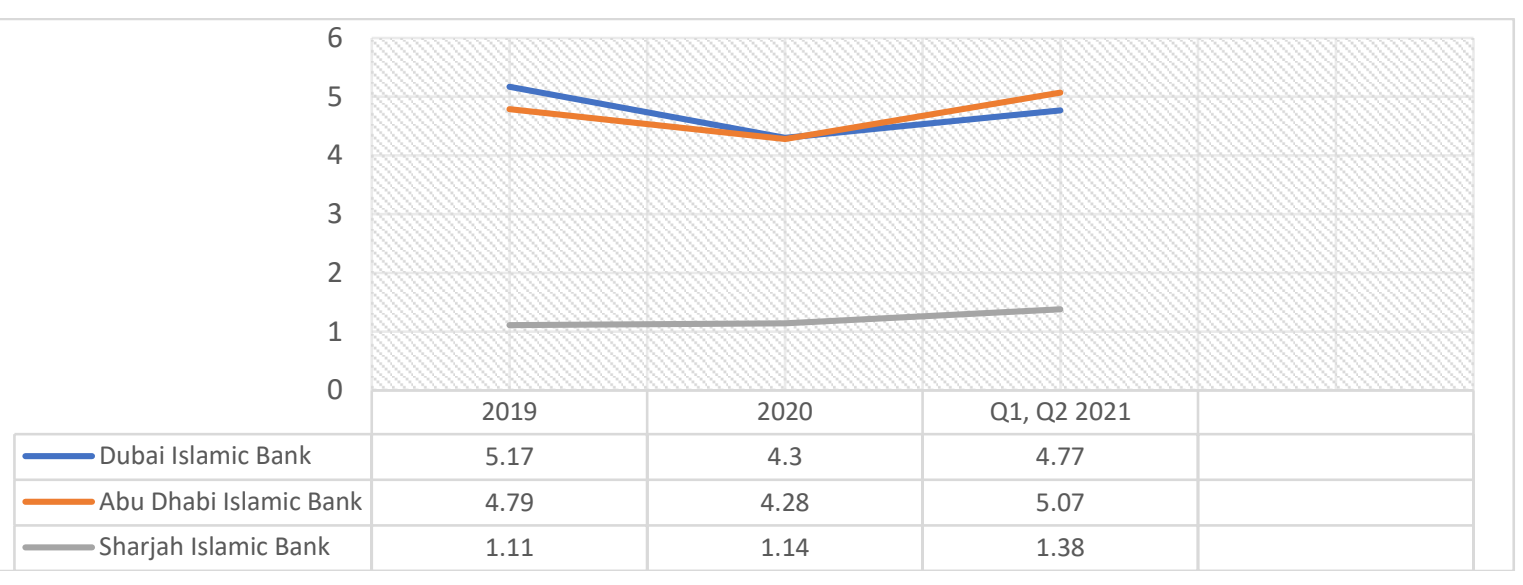

Figure 4. Islamic Banks Indices listed in UAE market

Source: Table 7

\section{Islamic Banks Indexes listed in Bahrain Market}

Bahrain Bourse is a self-regulating and multi-asset market, it provides a comprehensive range of services including listing services, trading services, settlement services and central depository for the various assets available in Stock exchange. Bahrain Islamic Index decreased by 650.19 (points) in 2020 compared to 760.04 (points) in 2019 (Bahrain Bourse, 2020; 2021). Bahrain, All Share Index closed in Q2 of 2021 at 1,587.97(Monthly Trading Bulletin, June 2021). The Islamic banks indices of four banks listed in Bahrain financial market is shown in table 8, and linear direction for the indices shown in figure 5 below.

Table 8. Analysis of Islamic Banks Indices listed in Bahrain market

\begin{tabular}{|c|l|c|c|c|}
\hline Country/Market & \multicolumn{1}{|c|}{ Banks } & $\mathbf{2 0 1 9}$ & $\mathbf{2 0 2 0}$ & Q1, Q2 2021 \\
\hline \multirow{3}{*}{ Bahrain } & Albaraka Islamic Bank & 0.32 & 0.28 & 0.22 \\
\cline { 2 - 5 } & ABC Bank & 0.45 & 0.35 & 0.29 \\
\cline { 2 - 5 } & GFH Financial Group- Bank & 0.24 & 0.16 & 0.18 \\
\cline { 2 - 5 } & Bahrain Islamic Bank & 0.12 & 0.10 & 0.09 \\
\hline
\end{tabular}

Source: GCC stock markets \& extracted from sa.investing.com 


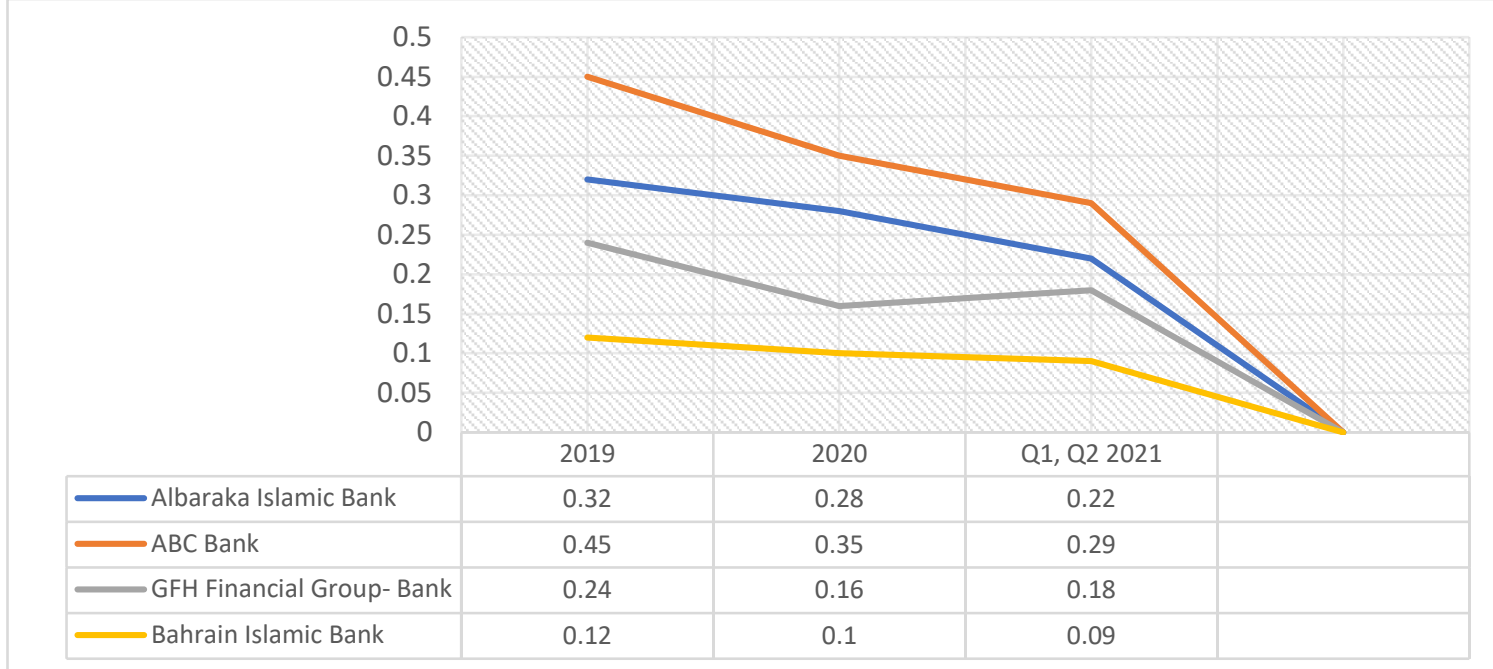

Figure 5. Islamic Banks Indices listed in Bahrain market

Source: Table 8

\section{Islamic Banks Indices listed in Oman market}

Bank Nizwa is a leading Islamic bank in Oman, the bank achieved a growth rate 9 per cent in net profit on despite in 2020, it faces the economic challenges and it achieved increasing in its market share for Islamic banking services which compliant Sharia and achieved growth in deposits amounted 16 per cent, and 20 per cent in finance for individuals, companies and entities. The bank achieved growth in profits 31 per cent during Q1 of 2021, the total assets amounted to $\$ 2.7$ billion in 2019 (Bank Nizwa, 2020). Bank Nizwa index listed in Oman financial shown in table 9 and linear direction for the index shown in figure 6 below.

Table 9. Analysis of Bank Nizwa Index listed in Oman market

\begin{tabular}{|c|c|c|c|c|}
\hline Country/Market & Banks & 2019 & 2020 & Q1, Q2 2021 \\
\hline Oman & Bank Nizwa & $\mathbf{0 . 0 9}$ & $\mathbf{0 . 1 0}$ & $\mathbf{0 . 1 0}$ \\
\hline
\end{tabular}

Source: GCC stock markets \& extracted from sa.investing.com.

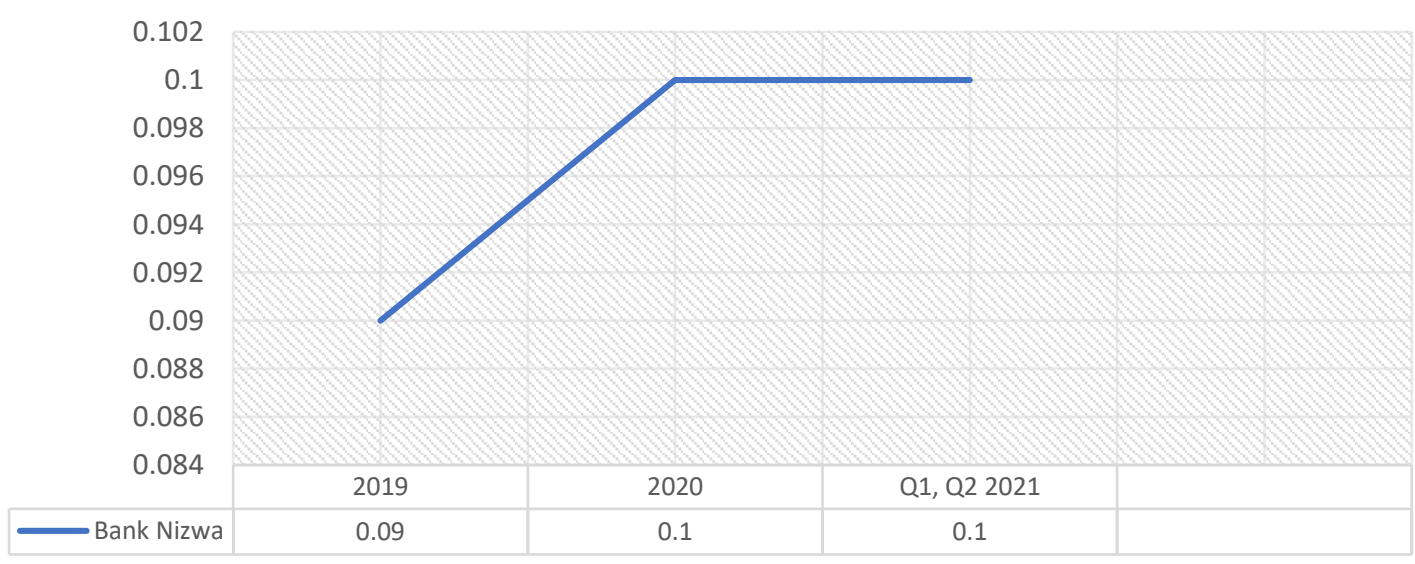

Figure 6. Bank Nizwa Index listed in Oman market

Source: Table 9 


\section{Islamic Banks Indexes listed in Qatar Market}

The Islamic banks assets in Qatar increase to $\$ 131.23$ billion in march 2021 compared to $\$ 117.42$ billion in march 2020, the assets of Islamic banks represented about 27.05 per cent of total assets of commercial banks in march 2021 (Galy, 2021).

The Islamic banks indices of three banks listed in Qatar financial market is shown in table 10 , and linear direction for the indices is depicted in figure no.7 below.

Table 10. Analysis of Islamic Banks Indices listed in Qatar market

\begin{tabular}{|c|l|c|c|c|}
\hline Country/Market & \multicolumn{1}{|c|}{ Banks } & $\mathbf{2 0 1 9}$ & $\mathbf{2 0 2 0}$ & Q1, Q2 2021 \\
\hline \multirow{3}{*}{ Qatar } & Qatar Islamic Bank & 15.80 & 15.99 & 16.91 \\
\cline { 2 - 5 } & Qatar International Islamic Bank & 7.84 & 8.45 & 9.10 \\
\cline { 2 - 5 } & Masraf Al Rayan & 3.75 & 4.05 & 4.38 \\
\hline
\end{tabular}

Source: GCC stock markets \& extracted from sa.investing.com.

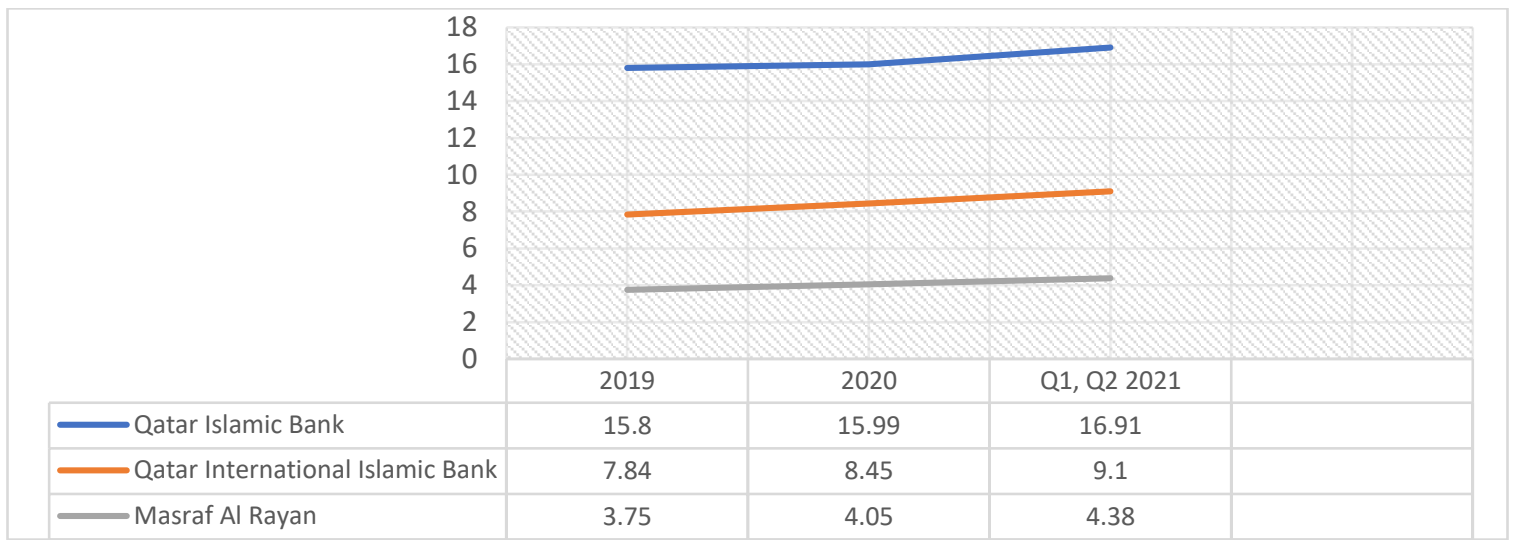

Figure 7. Islamic Banks Indices listed in Qatar market

Source: Table 10

\section{Islamic Banks Indices listed in Kuwait Market}

Kuwait Stock Exchange established a new main index 50 in 2020 which includes the top 50 companies listed in the main market which has high liquidity, the index 50 includes the Islamic banks in Kuwait. Kuwait stock market joined MSCI market indices in 2020, the market value of Kuwaiti capital market in 2020 amounted to $\$ 11.030$ billion, it recorded decreasing about 10 per cent compared to 2019 (Kuwait Bourse, 2020). According to the banks repots for the first half of 2020 , the total assets of Kuwaiti Islamic banks amounted to about $\$ 127.44$ billion. The Islamic banks indices of three banks listed in Kuwait financial market is shown in table 11, and linear direction for the indices shown in figure 8 below.

Table 11. Analysis of Islamic Banks Indices listed in Kuwait market

\begin{tabular}{|c|l|c|c|c|}
\hline Country/Market & \multicolumn{1}{|c|}{ Banks } & $\mathbf{2 0 1 9}$ & $\mathbf{2 0 2 0}$ & Q1, Q2 2021 \\
\hline \multirow{3}{*}{ Kuwait } & Kuwait Finance House & 624.83 & 647.17 & 739.83 \\
\cline { 2 - 5 } & Boubyan Bank & 535.92 & 559.00 & 631.00 \\
\cline { 2 - 5 } & Warba Bank & 236.67 & 223.22 & 243.50 \\
\hline
\end{tabular}

Source: GCC stock markets \& extracted from sa.investing.com 


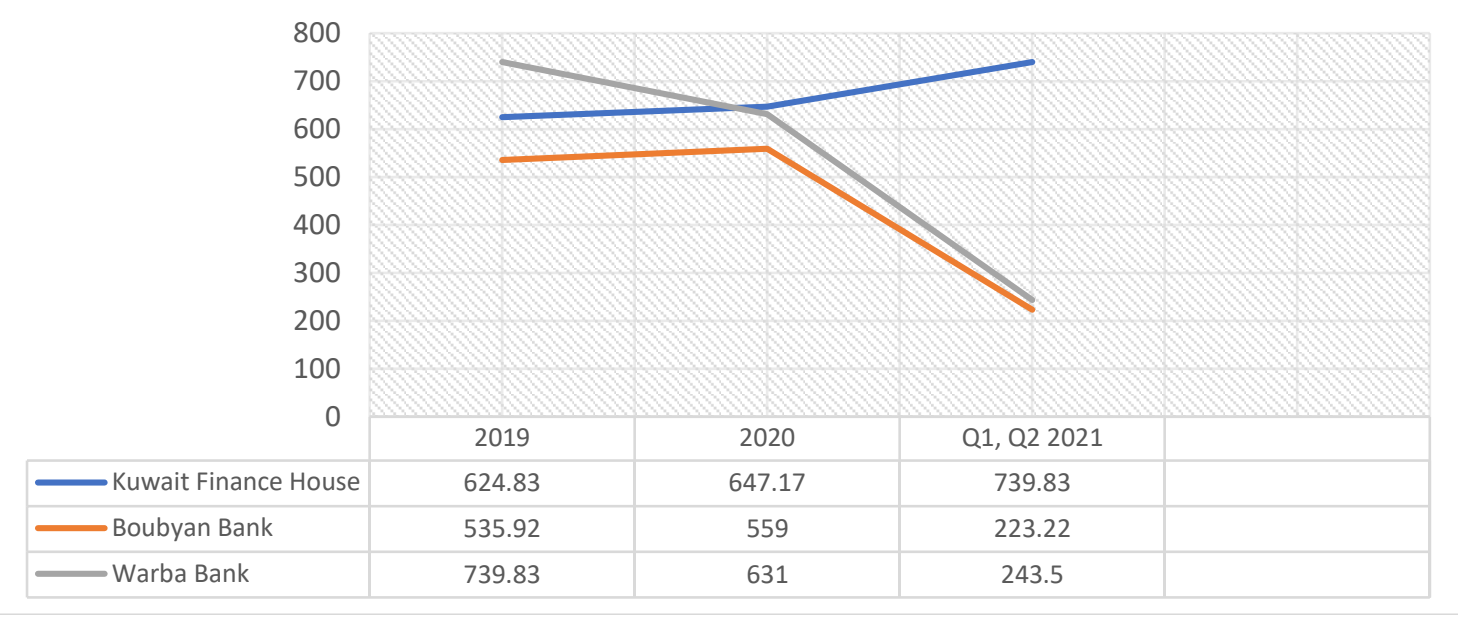

Figure 8. Islamic Banks Indices listed in Kuwait market Source: Table 11

According to the data in tables 6 to11, it has been discovered that the COVID-19 crisis affected indices of Islamic banks listed in GCC financial markets, the most indices recorded normal and slight decreasing in 2020, while some banks achieved growth in same year as Sharjah Islamic Bank, Bank Nizwa, Qatar Islamic Bank, Masraf Al Rayan, Kuwait Finance House and Boubyan Bank, and this means that Islamic banks has ability to response the crisis compared to the conventional banks. 1n 2021 the first and second quarters the Islamic banks indexes recorded positive rising. One can also visualize the linear direction for the indices of Islamic banks in GCC stock markets in figures 3 to 8.

\section{CONCLUSIONS AND SUGGESTIONS}

This study examines the performance of the Islamic banks' indices of GCC countries during the COVID-19 pandemic. The main objective is to understand impact of the COVID-19 crisis on the indices of Islamic banks listed in GCC stock exchanges. The results show that financial crisis due to the COVID-19 pandemic affected Islamic banks' indices in some markets of GCC countries (Saudi Arabia, Bahrain) as a result of the strict closing procedures, closing of the borders, suspension of flights, suspension of offline company activities, and the high finance costs, which negatively affected Islamic banks activities. Consequently, Islamic banks' indices declined in these stock exchanges during 2020. The banks' indices in 1Q and 2Q of 2021 recorded increasing in Saudi Arabia \& Bahrain markets because easing the restrictions and procedures of the closing and lockdown, while the impact on Islamic banks' indices in the remaining markets (Oman, Qatar, Kuwait and UAE) was insignificant, Islamic banks' indices recorded an increase during 2020 and 1Q and 2Q of 2021, because the financial systems in these countries adopted many of precautions during 2020, and the governments of respective countries took non-strict closing procedures, which helped to continue the financial and economic activities. Also the Islamic banks in these GCC countries have created impressive financial provisions to face the effects of the COVID-19 crisis.

Based on the findings, the study recommends that; (i). Governments in GCC countries (Saudi Arabia and Bahrain) should not take strict closing procedures during the COVID-19 crisis and in future. They must benefit from the flexible economy and financial policies which other GCC countries (Oman, Qatar, Kuwait and UAE) have adopted to face the COVID-19 crisis. (ii). The financial systems and Islamic banks in GCC countries (Oman, UAE, Qatar, and Kuwait) 
should continue to adopt precautions and positive policies, also to create the financial provisions to face impacts of the COVID-19 crisis.

\section{REFERENCES}

Ali, M., Anwar, U., \& Haseeb, M. (2021). Impact of COVID-19 on Islamic and Conventional Stocks in Indonesia: A Wavelet-Based Study. Bulletin Ekonomi Moneter Dan Perbankan, 24, 15-32.

Alpen Capital. (2021). Islamic Finance and Wealth Management Report June 29, 2021. Retrieved from http://www.alpencapital.com/downloads/reports/2021/Alpen-Capital-IslamicFinance-Industry-July-6-2021.pdf

Ali, R., \& Afzal, M. (2012). Impact of Global Financial Crisis on Stock Markets: Evidence from Pakistan and India. Journal of Business Management and Economics. 3(7), 275-282.

Aldasoro, I., Fender, I., Hardy, B., \& Tarashev, N. (2020). Effects of Covid-19 on the banking sector: the market's assessment (No. 12). Bank for International Settlements.

Abdullahi, S. I. (2021). Islamic equities and COVID-19 pandemic: measuring Islamic stock indices correlation and volatility in period of crisis. Islamic Economic Studies. https://doi.org/10.1108/IES-09-2020-0037.

Almonifi, Y. S. A., Rehman, S. U., \& Gulzar, R. (2021). The COVID-19 Pandemic Effect on the Performance of the Islamic Banking Sector in KSA: An Empirical Study of Al Rajhi Bank. International Journal of Management, 12(4), 533-547.

Arab Monetary Fund. (2021). Performance of Arab Stock Exchanges. Retrieved from https://www.amf.org.ae/ar/sites/default/files/econ/amdb/2021/1

Bahrini, R., \& Filfilan, A. (2020). Impact of the Novel Coronavirus on Market returns: Evidence from GCC Countries. Quantitative Finance and Economics, 4(4), 640-652.

Bahrain Bourse. (2020). Annual Report. Retrieved from https://www.bahrainbourse.com/sysimages/publication/documents/BHB_AR20_En.pdf

Bahrain Bourse. (2021). Monthly Trading Bulletin. June 2021. Retrieved from https://www.bahrainbourse.com/sysimages/publication/documents/June

Bank Nizwa. (2020). Annual Report. Retrieved from https://www.banknizwa.om/media/3398/bnar-2020-ar.pdf

Chaouachi, M., \& Slim, C. (2020). Current covid-19 impact on Saudi stock market: Evidence from an ARDL model.

El-Basuony, H. (2020). Effect of COVID-19 on the Arab Financial Markets Evidence from Egypt and KSA. IOSR Journal of Business and Management. 22(6), 14-21. 
Erfani, G., \& Vasigh, B. (2018). The impact of the global financial crisis on profitability of the banking industry: a comparative analysis. Economies, 6(4), 66.

Galy, A. (2021). The Islamic Banks Assets in Qatar. Mubasher. Retrieved from https://www.mubasher.info/news/3802652

Ganar, Y. B., Agrasadya, D., Apriansyah, M., Sahroni, Z., Sampurnaningsih, S. R., Rachmawaty, N., ... \& Sunarsi, D. (2020). The reaction of the sharia stock market in the early days of the Covid-19 pandemic in Indonesia. Systematic Reviews in Pharmacy, 11(11), 15161526.

Hidayat, S. E., Farooq, M. O., \& Alim, E. A. (2020). Impacts of the COVID-19 Outbreak on Islamic Finance in the OIN Countries. Indonesia: Komite Nasional Ekonomi dan Keuangan Syariah.

Irfan, M., Kassim, S., \& Dhimmar, S. (2020). Impact of Covid-19 on Islamic Stock Markets: An Investigation using Threshold Volatility and Event Study Models. International Journal of Islamic Economics and Finance, 4(1), 121-148.

Kassim, S. H. (2010). Global financial crisis and integration of Islamic stock markets in developed and developing countries. Institute of Developing Economies, Japan External Trade Organization.

Kuwait Bourse (2020). Annual Report. Retrieved from https://www.boursakuwait.com.kw/api/documents/boursa/1616587507361.pdf

Miniaoui, H., Syani, H., \& Chaibi, A. (2015). The Impact of Financial Crisis on Islamic and Conventional Indices of the GCC Countries. The Journal of Applied Business Research, $31(2), 357-370$.

Njiforti, P. (2015). Impact of the 2007/2008 Global Financial Crisis on the Stock Market in Nigeria. CBN Journal of Applied Statistics, 6(1), 49-68.

Noor, M. (2020). Islamic Finance in Saudi. Alwatan News. Retrieved from https://www.alwatan.com.sa/article/1047043

Saleh, R. B. (2020). The Impact of Covid-19 on the Shanghai Stock Exchange. Journal of Pure \& Applied Sciences, 19(6), 85-91.

Sansa, N., \& Hasan, A. (2020). The Impact of the COVID - 19 on the Financial Markets: Evidence from China and USA. Electronic Research Journal of Social Sciences and Humanities, 2(2), 29-39.

Shehar Yar, A. (2020). Impact of COVID-19 on Performance of Pakistan Stock Exchange Lahore. Retrieved from https://mpra.ub.uni-muenchen.de/101540 
Sutrisno, S., Panuntun, B., \& Adristi, F. I. (2020). Pandemic Impact of COVID-19 on the Stock Market Index and Return of Stock Market Index (event study on stock market index in Asian exchange). MODUS, 33(1), 47-66.

Sukmana, R., \& Kolid, M. (2012). Impact of global financial crisis on Islamic and conventional stocks in emerging market: an application of ARCH and GARCH method. Asian Academy of Management Journal of Accounting \& Finance, 31(2), 357-370.

S\&P Global Report (2021). Dow Jones Islamic Market GCC Index, Equity. Retrieved from www.spglopal.com/spdji

Thalassinos, E., Pintea, M., \& Iulia, R. (2015). The Recent Financial Crisis and Its Impact on the Performance Indicators of Selected Countries during the Crisis Period: A Repl. International Journal in Economics and Business Administration, 3(1), 3-20.

Wasiuzzaman, S. (2010). Impact of the global financial crisis on the volatility of the Malaysian stock market.

Zehri, C., Abdelbaki, A., \& Bouabdellah, N. (2012). Effects of The Current Financial Crisis on Islamic Banks Compared to Conventional Bank. Banks and Bank Systems, 7(1), 83-93.

\section{Copyrights}

Copyright for this article is retained by the author(s), with first publication rights granted to the journal. This is an open-access article distributed under the terms and conditions of the Creative Commons Attribution license (https://creativecommons.org/licenses/by/4.0). 